\title{
Histopathological alterations in bullfrog juveniles fed commercial rations of different crude protein levels ${ }^{1}$
}

\author{
José Teixeira de Seixas Filho ${ }^{2,3}$, Marcio Hipolito ${ }^{4}$, Ana Maria Cristina Rabello Pinto da \\ Fonseca Martins ${ }^{4}$, Eliane Rodrigues ${ }^{2}$, Airton Antonio Castagna ${ }^{2}$, Sílvia Conceição Reis \\ Pereira Mello²
}

\footnotetext{
1 Trabalho parcialmente financiado pela FAPERJ.

2 Centro Universitário Augusto Motta - UNISUAM. Av. Paris, 72 - Bonsucesso - RJ - Grupo AQÜISUAM - Laboratório de Pesquisa em Biologia e Mestrado em Desenvolvimento Local.

${ }^{3}$ Fundação Instituto de Pesca do Estado do Rio de Janeiro - FIPERJ. Alameda São Boaventura, 770 - Fonseca - Niterói, RJ.

${ }^{4}$ Centro de Pesquisa e Desenvolvimento de Sanidade Animal - Instituto Biológico de São Paulo.
}

\begin{abstract}
The relationship between the quality of dietary crude protein and health of bullfrog juveniles (Lithobates catesbeianus) was evaluated by necropsy and histopathological examination of animals. The histopathology results showed that animals fed different feeds, regardless of CP levels, presented lymphocytary hepatitis, colitis and flattened microvillosities; kidneys with areas of tubulonephrosis and renal tubule calcification; myocarditis and cardiac muscular fiber dissociation. Such injuries suggested a degenerative nutritional process, with development of inflammatory processes spread to all the organs. These findings suggested that the animals had been fed with proteins of low biological value, indicating, apparently, poor feed quality, that harmed the health of the frogs and, consequently, their performance. Complementary studies are necessary to understand the biochemical behavior of the bullfrog in its second phase of life, supplying data for a better understanding of the nutrition of these animals.
\end{abstract}

Key Words: animal nutrition, aquaculture, frog farming

\section{Alterações histopatológicas em imagos de rã-touro alimentados com diferentes rações comerciais}

\begin{abstract}
RESUMO - Avaliou-se a relação entre a qualidade da proteína bruta da ração e a sanidade de imagos de rã-touro (Lithobates catesbeianus) por meio de necropsia e exame histopatológico dos animais. Independentemente do nível de proteína bruta da ração, os animais apresentaram hepatite linfocitária; colite e achatamento das microvilosidades; rins com áreas de tubulonefrose e calcificação de túbulos renais; miocardite e dissociação das fibras musculares cardíacas. Essas lesões sugerem quadro degenerativo nutricional, com desenvolvimento de processos inflamatórios que se difundem para todos os órgãos. Esses achados indicam que os animais foram alimentados com proteínas de baixo valor biológico, como resultado de má qualidade das rações, o que compromete sua sanidade e seu desempenho. Estudos complementares são necessários para compreensão do comportamento bioquímico de rãs-touro em sua segunda fase de vida e para o entendimento da nutrição desses animais.
\end{abstract}

Palavras-chave: aquicultura, nutrição animal, ranicultura

\section{Introduction}

Native to the cold regions in south Canada and the northern United States, the Bull-frog (Lithobates catesbeianus) has a peculiar characteristic: it grows and reproduces quickly. This characteristic makes it well adapted when captive. In its original habitat, it can reach $170 \mathrm{~g}$ in four years and its ideal weight for slaughter is from 170 to $200 \mathrm{~g}$. However, when captive, it can reach this weight at 7 months old in the case of tropical regions, depending on the temperature, handling, feeding, and genetic potential (Lima \& Agostinho, 1988).

Brazil is today the world's second largest producer of frogs in captivity, with proprietary technology for breeding and processing. There are aproximately 600 frog producers in various states of the country and a third of them are in the state of Rio de Janeiro (Mello et al., 2006). Some stages of management are involved in situations that interfere with the general health of animals, including nutrition, sanitary and livestock management, which, if neglected, lead to the 
death of several animals, causing great economic losses. Nutritional handling is the main cause of the problems in frogculture. Furthermore, the composition of an adequate nutritional feed is directly related to protein content and the quality of these proteins (Hipolito et al., 2004).

Nutritional and sanitary handling aim to boost breeding by using feed to obtain nutrients in desired quantities. However, the imbalance of the carbohydrate and protein ratio in the feed given to animals, or their possible substitutes, undermines the whole nutritional process and can lead to morphological cell changes in various organs of the animals (Hipolito et al., 2004). These morphological changes are important causes of adaptation, injury and death of the cell. There are five types of cellular adaptation: atrophy, hypertrophy, dysplasia, metaplasia and hyperplasia. The types of cellular injury are cell swelling, fatty metamorphosis, necrosis and apoptosis (Kumar et al., 2008).

Therefore, the objective of this study was to evaluate the systemic histopathological changes in bullfrog juveniles (Lithobates catesbeianus) fed commercial feed used by frog farms in Rio de Janeiro with different formulations and indications of three crude protein levels.

\section{Material and Methods}

The experiment was conducted by the AQÜISUAM Research Group in the Biology Research Laboratory of UNISUAM, Rio de Janeiro. During the experimental period of 60 days, 360 bull-frog juveniles (Lithobates catesbeianus Shaw, 1802) from spawning were used, with average weight of $14.955 \mathrm{~g}( \pm 1.3 \mathrm{~g})$, distributed in twelve $1 \mathrm{~m}^{2}$ tanks, with a density of 30 animais $/ \mathrm{m}^{2}$ under water in a semi-immersed pond system.

The water was distributed in the tanks by polyvinyl carbon pipes, with replacement of $100 \%$ volume every 24 hours during the experimental period, and flow through PVC small pipeline installed in the back of the tanks and connected to the sewer. The water level inside the tanks was maintained by a knee type device adapted in the back of the tanks.

Commercial diets were used (Table 1) with different formulations, with indications of three levels of crude protein, CP $(28,36$ and $45 \%)$, each one with four replications, in a randomized complete design according to Seixas Filho et al. (1998). Forty eight bull-frog juveniles were used, three repetitions of each replicate per treatment, collected at the end of the experiment and subjected to autopsy, to verify histopathological changes in the liver, kidneys, intestines and heart. These organs were fixed in a metacarmim solution for 12 hours and kept in $70 \%$ alcohol. Subsequently, they were embedded in paraffin, cut $5 \mu \mathrm{m}$ thick in microtome and stained with hematoxylin and eosin to observe the slides using light microscopy.

Table 1 - Composition of commercial feed used for Bull-frog juveniles

\begin{tabular}{lccc}
\hline Declared composition & \multicolumn{3}{c}{ Crude protein level in the food } \\
\cline { 2 - 4 } (levels of guarantee) $^{1}$ & $28 \%$ & $36 \%$ & $45 \%$ \\
\hline Maximum moisture & $13.0 \%$ & $13.0 \%$ & $13.0 \%$ \\
Crude protein (CP) & $28.0 \%$ & $36.0 \%$ & $45.0 \%$ \\
Crude fat (minimum) & $04.0 \%$ & $08.0 \%$ & $08.0 \%$ \\
Crude fibre (maximum) & $10.0 \%$ & $07.0 \%$ & $07.0 \%$ \\
Ashes (maximum) & $14.0 \%$ & $14.0 \%$ & $14.0 \%$ \\
Calcium (maximum) & $03.0 \%$ & $03.1 \%$ & $03.1 \%$ \\
Phosphorus (minimum) & $0.60 \%$ & $02.5 \%$ & $02.5 \%$ \\
Calculated composition & & & \\
Matter:carbohydrates & & & \\
Crude fat & 60.57 & 48.82 & 18.08 \\
Mineral matter & 3.16 & 4.45 & 6.79 \\
Crude protein & 11.44 & 8.50 & 9.81 \\
Dry matter:carbohydrates & 27.93 & 36.18 & 41.85 \\
Crude fat & 54.8 & 44.97 & 16.30 \\
Crude protein & 3.50 & 4.83 & 7.53 \\
Mineral matter & 30.88 & 39.27 & 46.43 \\
Dry matter & 12.65 & 9.23 & 10.89 \\
Moisture & 90.46 & 92.11 & 90.14 \\
\hline
\end{tabular}

Basic composition: soybean meal, fish meal, wheat bran, corn gluten meal $60 \%$, meat and bone meal, corn, blood meal, fish oil, calcium carbonate, dicalcium phosphate, add salt, vitamins ${ }^{1}$ and minerals $\mathrm{s}^{2}$, anti-oxidant (ethoxyquin) $-250 \mathrm{~m}$. ${ }^{1}$ Composition per kg: vit. A - $12.000 \mathrm{UI}$; vit. $\mathrm{D}_{3}-4.000 \mathrm{UI}$; vit. E - $150 \mathrm{UI}$; vit $\mathrm{K}-10 \mathrm{UI}$; folic acid $-10 \mathrm{mg}$; biotin $-0,8 \mathrm{mg}$; choline $-500 \mathrm{mg}$; niacin $-150 \mathrm{mg}$; calcium pantothenate- 50 ; thiamine - $30 \mathrm{mg}$; riboflavin $-30 \mathrm{mg}$; pyridoxine B6-

$30 \mathrm{mg}$; vit. B $12-35 \mu \mathrm{g}$; vit.C $-300 \mathrm{mg}$.

2 Composition per kg: Mg - $700 \mathrm{mg} ; \mathrm{Mn}-30 \mathrm{mg} ; \mathrm{Zn}-200 \mathrm{mg} ; \mathrm{Cu}-15 \mathrm{mg} ; \mathrm{Fe}-$ $100 \mathrm{mg}$; I - $1 \mathrm{mg}$; Se - 0,3 mg.

3 Analysis from Nutrition Laboratory of DZO - UFV.

\section{Results and Discussion}

Primary or secondary nutritional disorders can lead to morphological changes which cause symptoms relatively late, although the appearance of morphological changes is not related to functional deficits, as they may arise well before anatomical changes are evident.

Macroscopically, the livers, were pale (data not shown), and in the histopathological examination, there was intense focal mononuclear inflamatory infiltrate in the subcapsular regions and hepatic lobules, in addition to venous congestion (Figures 1, 2 and 3).

These changes may be associated with the commercial formulations of the diets used, since they are designed for fish because there is no unique formulation for the bullfrog at any of its stages of development. The lack of a specific product may interfere with the nutritional process of bull-frog juveniles, because during this stage, the frogs have a digestive system suitable for carnivores, with short intestines. Because these diets tend to meet more of the characteristics of omnivorous animals, the bull-frog juvenile 
does not adapt to this type of feed, which leads to a process of prolonged protein-calorie malnutrition (Hipólito, 2003). This process involves changes in liver function due to lack of good quality protein, which may cause serious injuries in this organ with clear reduction in the growth rate and death of the animal (Hipólito et al., 2001). Moreover, it is reported in the literature that the Mycotoxicoses, in association with the deterioration of the diet, may cause blood congestion, and focal areas of interstitial hepatitis and hepatitis (Hipólito et al., 2001).

Lesions were observed in the hindgut of animals characterized by mononuclear enteritis and colitis, with loss or flattening of the longitudinal folds and hyperplasia of epithelial cells (Figures 4, 5 and 6), when the intestinal structure of these animals was compared to healthy frogs (George et al., 1998). The loss or flattening of the longitudinal folds contradicts literature reports of a sharp reduction in the height of the intestinal villi in weaned piglets, caused by supplying a diet of low nutritional value (Lopes et al., 2004). Furthermore, it has been shown that adult bull-frogs which have suffered nutritional intoxication with protein deficiency present peeling and atrophy of the longitudinal folds of the intestinal epithelium (Hipólito et al., 2001). The intake of feed with low protein quality can cause lesions in the intestinal tissue caused by stress and infectious agents, in

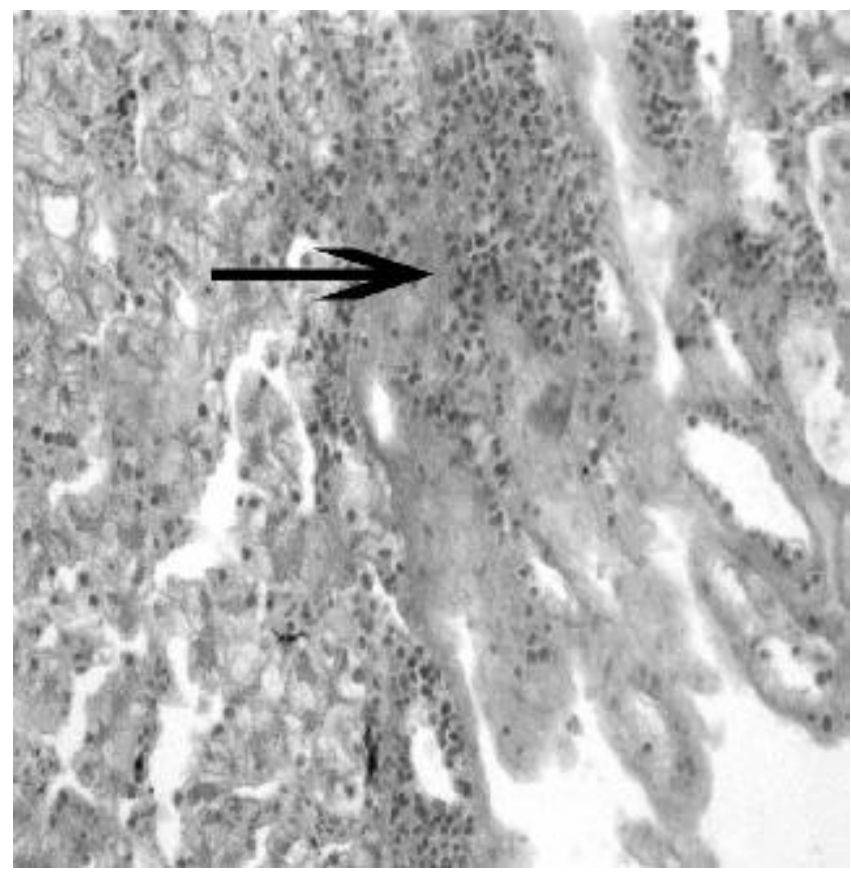

Presence of lymphocytic hepatitis with large numbers of mononuclear cells (arrow). The same lesions were observed in imagoes fed diets containing 28 and $36 \% \mathrm{CP}$.

Figure 1 - Photomicrograph of liver image of bull-frog juveniles fed diets of $45 \%$ CP stained with HE, $100 \mathrm{X}$.

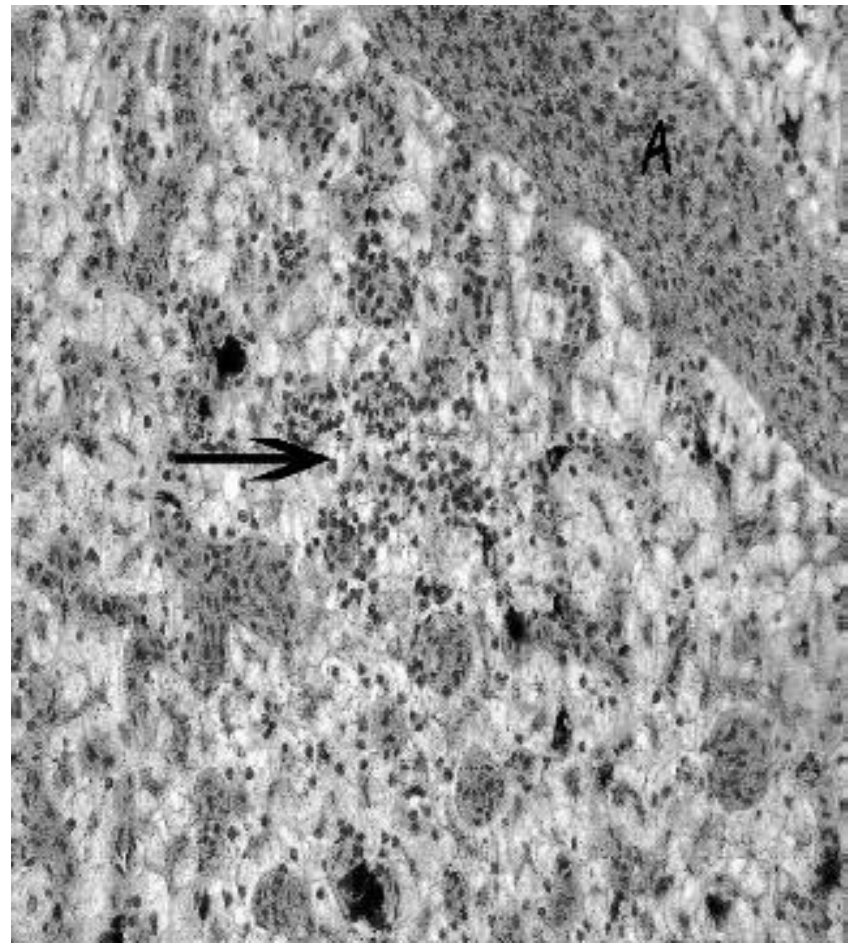

Presence of focal hepatitis and congestive vessels sinusoids filled with erythrocytes (A) and an outbreak of mononuclear hepatitis (arrow). The same lesions were observed in bull-frog juveniles fed with diets containing 28 and $36 \% \mathrm{CP}$.

Figure 2 - Photomicrograph of liver image of bull-frog juveniles fed diets of $45 \%$ CP stained with HE, $100 \mathrm{X}$.

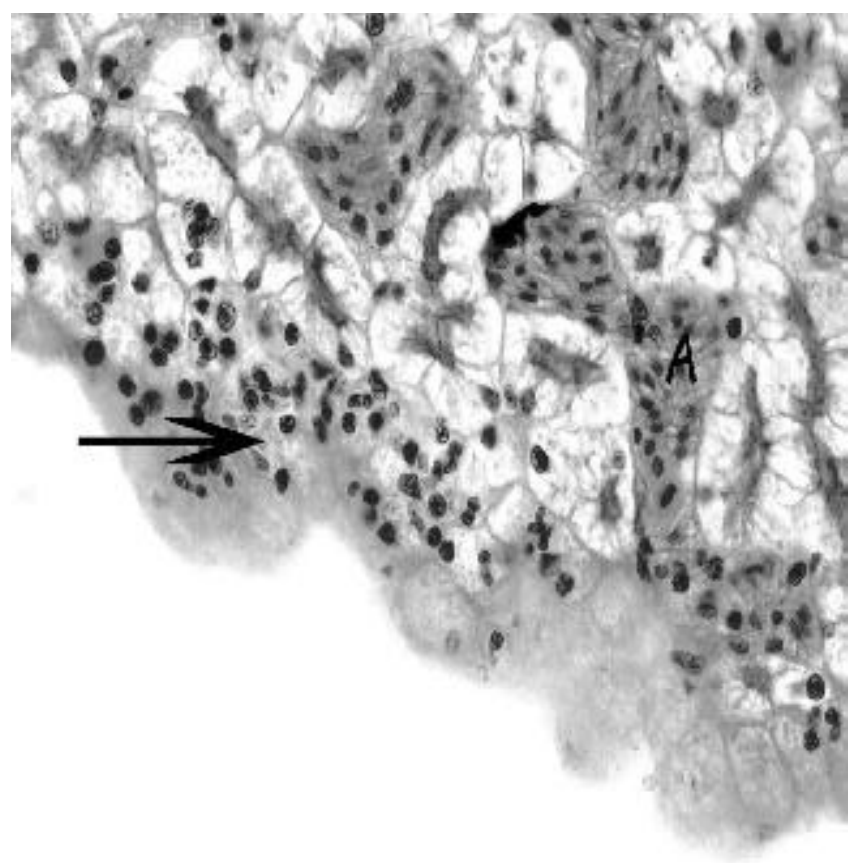

Presence of subcapsular hepatitis (arrow) and venous congestion (A). The same lesions were observed in bull-frog juveniles fed with diets containing 28 and $36 \% \mathrm{CP}$.

Figure 3 - Photomicrograph of liver image of bull-frog juveniles fed diets of $45 \% \mathrm{CP}$ stained with HE, $200 \mathrm{X}$. 
addition to the development of an intense inflammatory response to fight these agents, which could, at least in part, explain the cases of enteritis and mononucleaer colitis.

Microscopic examination of renal tissue showed tubule nephrosis, with tubular degeneration and destruction of tubular epithelial cells, which suggested renal failure (Figure 7), that may be associated with prolonged feeding

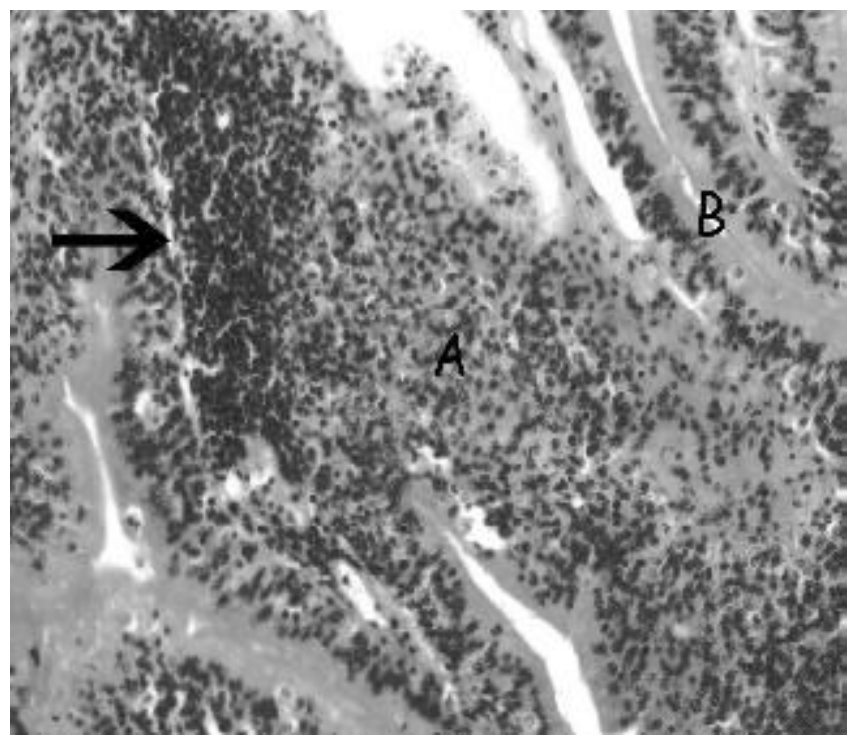

Presence of colitis in lymphocyte proliferation (arrow) and proliferation of epithelial cells (A) and area with normal monolayer of epithelial cells (B). The same lesions were observed in bull-frog juveniles fed diets containing 28 and $36 \% \mathrm{CP}$.

Figure 4 - Photomicrography of hindgut of bull-frog juveniles fed diets of $45 \%$ CP stained with HE, $100 \mathrm{X}$.

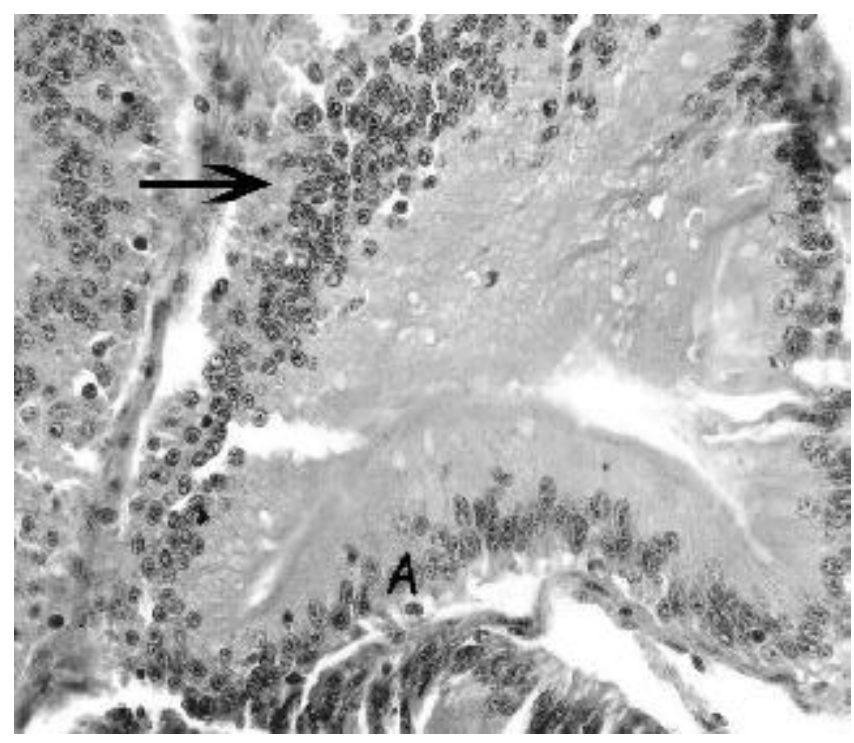

Presence of hypertrophy and epithelial hyperplasia (arrow). Normal area (A) The same lesions were observed in juvenile bull-frog fed diets containing 28 and $36 \% \mathrm{CP}$.

Figure 5 - Photomicrography of hindgut of bull-frog juveniles fed diets of $45 \%$ CP stained with HE, $200 \mathrm{X}$. with low quality protein, as it has been shown in humans that patients with short bowel syndrome from malnutrition develop a framework for renal failure, caused by gromerulonefrose (Durks et al., 2007).

In some cases, the bull-frog juvenile also showed tubular calcification (Figure 7), which can be explained by renal failure, which leads to renal decrease of

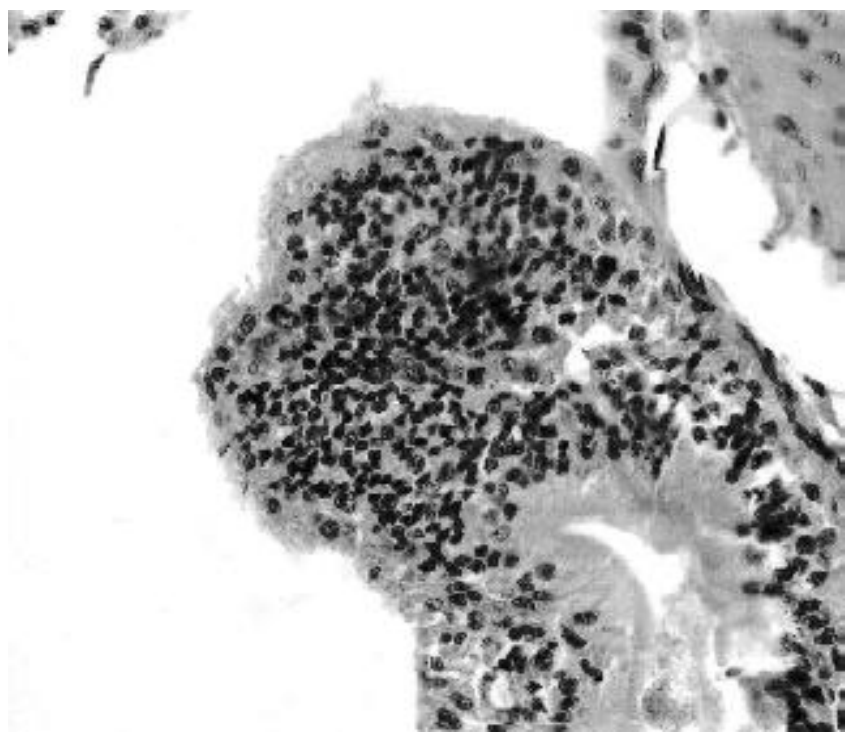

Presence of lymphocyte hyperplasia (arrow). The same lesions were observed in bull-frog juveniles fed diets containing 28 and $36 \% \mathrm{CP}$.

Figure 6 - Photomicrography of hindgut of bull-frog juveniles fed diets of $45 \%$ CP stained with HE, $200 \mathrm{X}$.

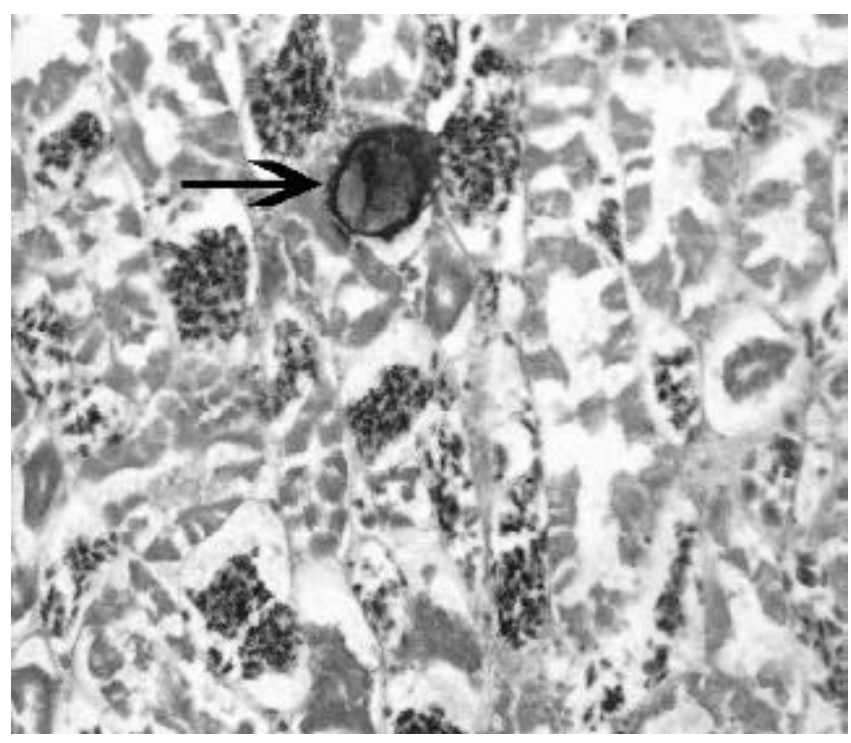

Presence of tubule-nephrosis with tubular degeneration (A) and calcification of renal tubules (arrow). The same lesions were observed in bull-frog juveniles fed diets containing 28 and $36 \% \mathrm{CP}$

Figure 7 - Photomicrograph of kidney of bull-frog juveniles fed diets of $45 \%$ CP stained with HE, 100 X. 
potassium, the main cause of renal hypercalcemia, and that change in the calcium metabolism may account for by the calcification observed in the kidneys of bull-frogs fed diets of low nutritional value (Rubin, 2006).

Finally, the histopathology of heart tissue showed dissociation of myocardial fibers with focal areas of myocarditis, suggesting death of cardiomyocytes and

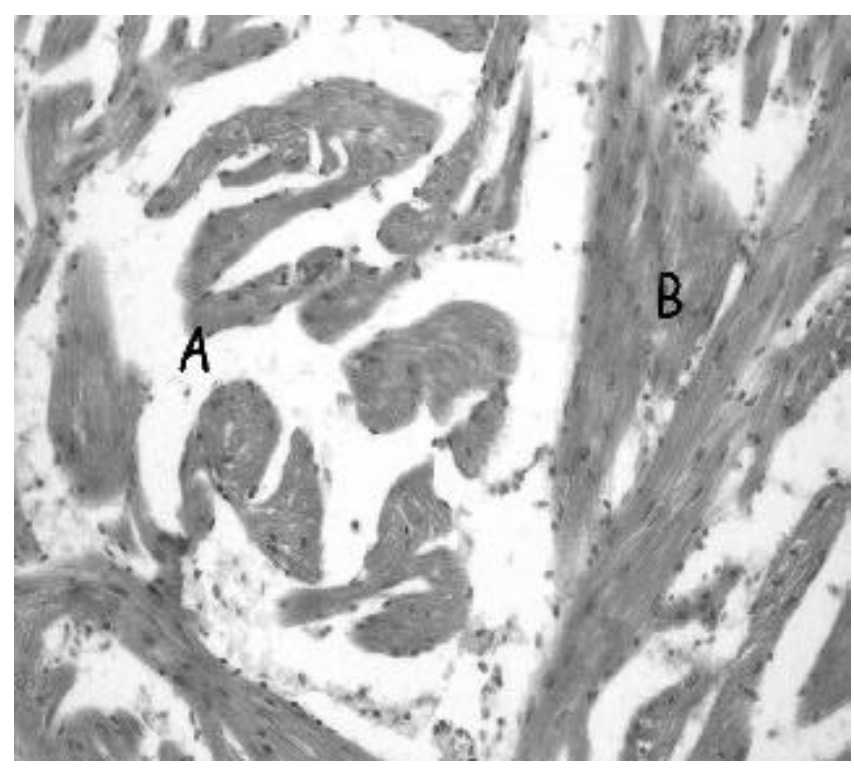

Decoupling of the fibers (A) and normal area (B) of the myocardium. The same lesions were observed in bull-frog juveniles fed diets containing 28 and $36 \% \mathrm{CP}$

Figure 8 - Photomicrography of heart of bull-frog juveniles fed diet with $45 \%$ CP stained with HE, $100 \mathrm{X}$.

\section{Conclusion}

The histopathological findings suggested that the animals were fed in a manner which is inappropriate to their digestive system and/or the feed contained proteins of low biological value, therefore with poor quality diets, which harmed their health and performance.

\section{Literature Cited}

DÜRKS, P.T.; ARAÚJO, J.L.; SILVA, R.S. et al. Síndrome do intestino curto: causas, tratamento, complicações e prognóstico em Pelotas, Rio Grande do Sul, Brasil. Revista Brasileira de Nutrição Clínica, v.22, n.1, p.5-9, 2007.

GEORGE L.L.; ALVES C.E.R.; CASTRO R.R.L. Histologia comparada. 2.ed. São Paulo: Rocca, 1998. 286p.

HIPOLITO, M.; LEME, M.C.M.; BACH, E.E. Lesões anátomohistopatológicas em rãs-touro (Rana catesbeiana Shaw, 1802) associadas à deterioração da ração. Arquivos do Instituto de Biologia, v.68, n.1, p.111-114, 2001 . congestive heart failure (Figures 8 and 9). One explanation for these changes may be the fact that the reduction in the absorption of proteins with high nutritional value leads to a reduction in the supply of iron to animals and can cause anemia, which would reduce the availability of oxygen in the blood and cardiac ischemia, a major cause of cardiomyopathy in mammals (Rubin, 2006).

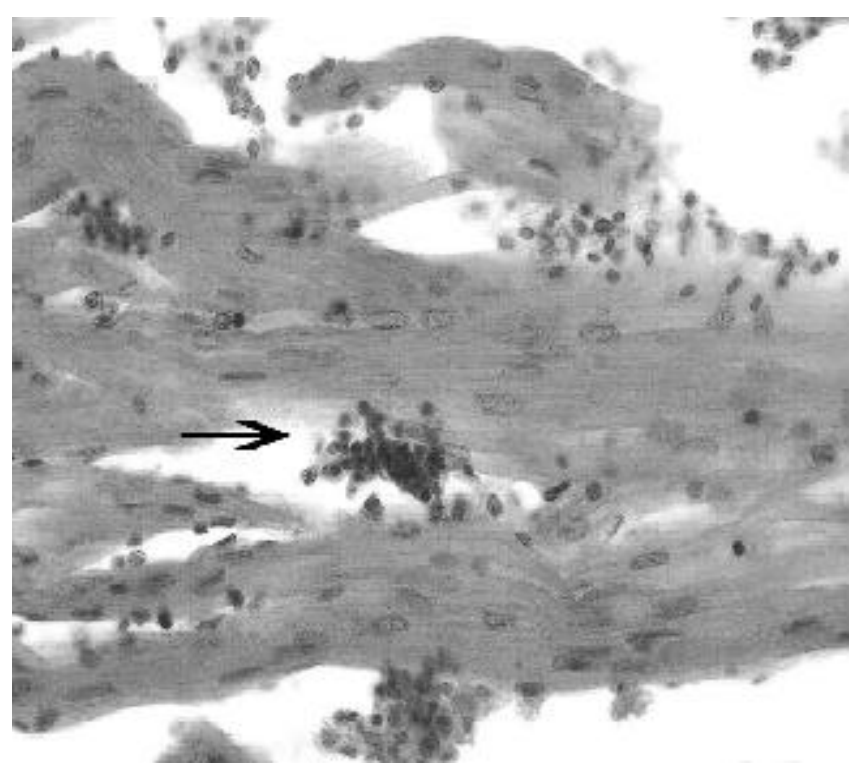

Presence of focal areas of myocarditis (arrow). The same lesions were observed in bull-frog juveniles fed diets containing 28 and $36 \% \mathrm{CP}$.

Figure 9 - Photomicrography of the heart of bull-frog juveniles fed diets with $45 \% \mathrm{CP}$ stained with HE, $200 \mathrm{X}$.

HIPOLITO, M. Deficiência protéica e demais patologias associadas ao fígado de rãs-touro (Rana catesbeiana SHAW, 1802). Boletim do Instituto de Pesca, v.34, p.29-33, 2003.

HIPOLITO, M.; MARTINS, A.M.C.R.P.F.; BACH, E.E. Aspectos bioquímicos em fígado de rãs-touro (Rana catesbeiana SHAW, 1802) sadias e doentes. Arquivos do Instituto de Biologia, v.71, n.2, p.147-153, 2004.

KUMAR, V.; ABBAS, A.K.; FAUSTO, N. et al. Robbins patologia básica. 8.ed. Rio de Janeiro: Elsevier, 2008. 1048p.

LIMA, S.L.; AGOSTINHO, C.A. A criação de rãs. Rio de Janeiro: Edições Globo, 1988. 187p.

LOPES, E.L.; JUNQUEIRA, O.M.; ARAÚJO, L.F. et al. Fontes e níveis de proteína em rações iniciais para leitões desmamados aos 21 dias de idade. Revista Brasileira de Zootecnia, v.33, n.6, p.2292-2299, 2004.

MELLO, S.C.R.P.; MANO, S.; FRANCO, R.M. et al. Avaliação bacteriológica e físico-química da polpa de dorso de rã obtida por separação mecânica. Brazilian Journal of Food Technology, v.9, n.1, p.39-48, 2006.

RUBIN, E. Patologia - Bases clinicopatológicas da medicina. 4.ed. Rio de Janeiro: Guanabara Koogan, 2006. 1648p.

SEIXAS FILHO, J.T.; MELLO, S.C.R.P.; SILVA, J.M.F. et al. Efeito dos níveis de energia e proteína bruta no desempenho de girinos (Rana catesbeiana Shaw, 1802). Revista Brasileira de Zootecnia, v.27, p.664-669, 1998. 